\title{
Peertechz
}

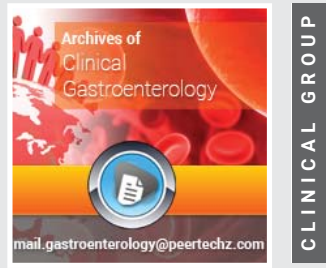

\section{Gastrointestinal and hepatic involvement in patients with SARS-CoV-2 infection}

\author{
Gupta Rama1* and Kaushal Vandana² \\ ${ }^{1}$ Associate Professor, Department of Microbiology, Dayanand Medical College \& Hospital, Ludhiana, \\ Punjab (141001), India \\ ${ }^{2} \mathrm{Sr}$ Consultant, Department of Microbiology, Dayanand Medical College \& Hospital, Ludhiana, Punjab \\ (141001), India
}

Received: 11 January, 2021

Accepted: 21 January, 2021

Published: 22 January, 2021

*Corresponding author: Gupta Rama, Associate Professor, Department of Microbiology, Dayanand Medical College \& Hospital, Ludhiana, Punjab (141001), India, Tel: 9814119432; E-mail: ramagupta1404@yahoo.com Keywords: COVID-19; SARS-CoV-2; Gastrointestinal; Hepatic; ACE2 receptors

https://www.peertechz.com

Check for updates

\section{Abstract}

The coronavirus disease-2019 (COVID-19) is primarily a disease of the respiratory system and is manifested by an infectious pneumonia, with fever, cough and breathlessness as the most common presenting symptoms. However quite a few number of the patients may suffer involvement of gastrointestinal system and liver. There is mild to moderate abnormality in the levels of liver enzyme observed in the patients with hepatic involvement, whereas gastrointestinal symptoms include nausea, vomiting and diarrhea. Nonetheless, gastrointestinal disease in COVID-19 patients may present with severe life threatening conditions, like gastrointestinal bleed, intestinal ischemia, acute liver failure and necrosis. The virus bind and invade the cells through Angiotensin Converting Enzyme 2(ACE2) receptors, which are expressed not only on endothelial cells of lung alveoli but also markedly expressed on epithelial lining of the oral mucosa, intestinal mucosa and cholangiocytes. Viral RNA has also been detected from stool specimens of COVID-19 patients, even during the convalescent phase, which is a matter of concern for the transmission of the disease via fec0oral route and needs to be elucidated.

\section{Introduction}

The severe acute respiratory syndrome-coronavirus-2 (SARS-CoV-2), a novel coronavirus is responsible for an ongoing pandemic and the disease has been named as coronavirus disease-2019 (COVID-19) by the World Health Organization $[1,2]$. At of the time of submission of this article, the number of confirmed cases of COVID-19 has crossed fifty seven million and wiped away I population of more than 1.3 million with a mortality of approximately $3 \%$ and involving almost the entire world. The disease is primarily a respiratory disease with fever, cough, malaise and breathlessness being the outstanding features and resembles diseases caused by other coronaviruses viz. Severe Acute Respiratory Syndrome (SARS) and Middle East Respiratory Syndrome (MERS) [3-5]. A small but significant numbers of patients infected with COVID-19 may present with gastrointestinal symptoms like diarrhea, vomiting and nausea initially, with [6] or without [7] respiratory symptoms. Additionally increasing number the patients are presenting with hepatic manifestations. Another important observation reported in patient with GI symptoms is the shedding of the virus in their stool samples for an additional period of $2-14$ days , after pulmonary symptoms have resolved [8-10].

Although the primary route of transmission of COVID-19 remains the respiratory, via aerosolized droplet, yet there is a possibility of feaco-oral transmission of the virus keeping in mind the fact that an asymptomatic individual or individuals before the manifestations of the symptoms can transmit the infection and also the virus has been detected in the stool specimens of the convalescent individuals even after negative viral RNA from nasopharyngeal swab [8,11-13]. This article will emphasize upon gastrointestinal and hepatic manifestations in patients with COVID-19 infection and their proposed mechanisms.

\section{Gastrointestinal manifestations}

The various studies published on epidemiological and clinical presentations of COVID-19 have shown that approximately $3-40 \%$ patients may present with one or the other gastrointestinal symptoms like diarrhea, nausea, 
vomiting and abdominal pain [14-18]. A study from Wuhan, China have documented that $39.6 \%$ of COVID-19 patients complained about gastrointestinal symptoms, including nausea, diarrhea, poor appetite, abdominal pain, belching, and emesis. However the most common GI presentation in these patients was nausea $(17.3 \%)$ followed by diarrhea $(12.9 \%)$, abdominal pain $(5.8 \%)$, belching( $5 \%$ )and vomiting $(5 \%)$ [18] Another study has reported an incidence of diarrhea in $8 \%$ of the patients with COVID-19 disease [19]. A study from Singapore have shown that among the 18 hospitalized patients with PCR-confirmed SARS-CoV-2 infection, four of the patients developed nausea, vomiting, and/or diarrhea, and 3 of the patients developed abnormal liver function. The authors have stated that these patients probably had developed the gastrointestinal symptoms subsequent to treatment with lopinavir-ritonavir [3]

Further, a meta-analysis of 60 studies involving a total of approximately 4000 patients, the pooled prevalence of all gastrointestinal symptoms was $17.6 \%$ with statistically significant variations noted among studies. The pooled prevalence of loss of appetite was( $26.8 \%)$, nausea/vomiting was $10.2 \%$ of diarrhea was $12.5 \%$, and of abdominal pain/ discomfort was $9.2 \%$. However not all the studies included in the meta-analysis have reported individual GI symptoms [20]. In contrast, another meta-analysis including approximately 6000 patients reported the presentation of GI symptoms in only $9 \%$ of the patients [15].

Another common GI symptoms reported in patients with COVID-19 are, loss of smell, and dysgeusia/ageusia. Of the total 59 hospitalized patients in a study reported that $33.9 \%$ of the patients had either ansomia or dysgeusia, whereas $18.6 \%$ of the patients reported with both taste and olfactory disorders. Twelve patients $(20.3 \%)$ presented the symptoms before the hospital admission, whereas 8 (13.5\%) experienced the symptoms during the hospital stay $[21,22]$. Therefore loss of smell and taste during the early phase of the disease can be used as a marker for the diagnosis of the disease, at least during the pandemic as this features are non specific and could be present in other viral infections as well [23].

A case of mesenteric ischemia with severe hypotension, a rare gastrointestinal manifestation of COVID-19 has also reported in a 62-year- man. The clinical history of the patient included three days of abdominal pain and bilious vomiting prior to hospital admission in an unconscious state. The patient had comorbidities like obesity, arterial hypertension, diabetes mellitus type 2 and hepatic cirrhosis (non-alcoholic steatohepatitis + hepatitis B). The patient's nasopharyngeal swab and bronco-alveolar lavage was tested negative for SARS CoV-2 and CT chest was unremarkable. However, abdominal CT findings were highly suggestive for small bowel ischemia. Histological examination of the resected bowel showed complete ischemic necrosis, recent thrombosis and severe endothelial inflammatory infiltration in inferior vena cava and superior mesenteric vein. In view of the ongoing pandemic ISH (in situ hybridization) on the resected small bowel specimen was performed to detect the SARSCoV-2 spike protein mRNA using VnCov2019- S probe and the test confirmed SARS
CoV-2 presence in the intestinal mucosa [24]. interestingly, quite a few studies have reported gastrointestinal symptoms without any respiratory symptoms [25,26]. One of the unusual presentations in this context was hemorrhagic colitis reported in a 71-year-old female and was tested positive on nasopharyngeal swab SARS-CoV-2 RTPCR. The lower GI bleed in this patient was attributed to SARS-CoV-2 after ruling out other etiologies [27]. Another rare gastrointestinal manifestation of the COVID-19 is the gastrointestinal bleed during the initial phase of the disease, reported from a 53 year old male patient presented to the emergency department with epigastric pain, diarrhea, and respiratory symptoms. The patient had comorbid conditions like hypertension, diabetes mellitus, and chronic renal failure [28] On the contrary, most of the other COVID-19 gastrointestinal bleeding cases are the critical or terminally sick patients $[29,30]$.

\section{Hepatic manifestations}

Recent epidemiological and clinical data on COVID-19 have elucidated that a moderate to severe liver function abnormality may be detected in these patients, with alanine Aminotransferase (ALT) or aspartate Aminotransferase (AST) above the normal range [31]. A study from China including 7736 hospitalized patients with Covid-19, published during the early phase of pandemic, , have reported that total bilirubin, AST and ALT were elevated in $10.5 \%, 21.3 \%$ and $22.2 \%$ of patients respectively [14]. There are several large-scale case studies published on the clinical presentation and laboratory finding in the patients with COVID-19. These studies indicate that $14-53 \%$ of the cases had liver dysfunction during the progression of the disease. Severity of the liver dysfunction has been correlated with adversity of the COVID-19 disease progression as abnormally high AST levels were observed in $62 \%$ of the patients in need of intensive care, whereas only $25 \%$ of the patient who did not require ICU care had elevated AST levels $[9,14,16,18]$. There is not much data available on liver pathology in COVID-19 except a report of one patient who underwent a autopsy. The liver autopsy specimens of the patient with COVID-19 showed microvesicular steatosis with mild lobular and portal inflammation. However the etiology behind the liver damage could not be ascertained as the injury could have been caused by either directly by invasion of the liver by SARS-CoV-2 infection or drug-induced [32]. In addition to the above discussed liver dysfunctions an isolated case report has associated acute hepatitis with COVID- 19 Infection, presenting much before the appearance of respiratory symptoms [33].

\section{Mechanism for the gastrointestinal and hepatic damage}

Different mechanisms and theories have been put forwarded for the gastrointestinal and hepatic damage caused by SARS COV-2.

Viral invasion: Binding and Invasion of the virus in the target cell is a phenomenon known as tissue tropism and it is a receptor -legend interaction between the host cell and the pathogen. In case of SARS-COV-2 it has been found that receptors on the host cell are Angiotensin-Converting enzyme 2 (ACE 2) complementary to virus transmembrane spike

Citation: Rama G, Vandana K (2021) Gastrointestinal and hepatic involvement in patients with SARS-CoV-2 infection. Arch Clin Gastroenterol 7(1): 007-010. 
glycoprotein (S-protein). These receptors are present on the surface of different human cell types including alveolar cells (AT2 cells) of the lung tissue and also on certain intestinal epithelial cells in the ileum and colon [34-35]. The active multiplication of the virus in the gut epithelium has already been proved by virus culture as well as direct visualization by electron microscopy [10] Histology of the autopsied specimen of a patient with COVID-19 had also shown degeneration and necrosis of the gastrointestinal mucosa [36] Binding, invasion and multiplication of the virus to intestinal epithelial cells can very well explain the pathogenesis of gastrointestinal manifestations associated with COVID-19. In the context of binding of virus to intestinal epithelial cells and shedding of the virus in the stool sample $[9,13]$ also fecal-oral transmission of the virus needs to be studied. Additionally, ACA 2 receptors are also widely expressed on the epithelial cells of the mucosa of the oral cavity [37]. These findings could explain the underlying pathogenetic mechanism of taste and olfactory disorders in SARS-CoV-2 infection.

A preliminary study has suggested that cholangiocytes are also enriched in expression of ACE2 receptors indicating that SARS-COV-2 might directly bind to ACE2 positive cholangiocytes and indirectly dysregulate the liver function. Nonetheless, histology of liver tissue from a patient who died from COVID-19 did not showed any viral inclusion, an indirect evidence of absence of active multiplication of the virus in the hepatocytes and also the absence of ACE 2 receptors on the liver cells [38].

Ischemic damage: Ischemia/ hypoxia due to respiratory complications of COVID-19, leading to acute respiratory distress syndrome (ARDS) can also damage the liver [39-40] A study using an in vitro mouse model of ischemia and hypoxia have demonstrated hepatocytes necrosis and inflammatory cell infiltration of the liver [41] because of continuous release of reactive oxygen species and its peroxidation products [42].

Cytokine storm: Various studies have reported that though there was a decrease in peripheral $\mathrm{CD} 4$ and $\mathrm{CD} 8 \mathrm{~T}$ cell counts in the patients with COVID-19 severe disease, however these cells are in hyperactive state, leading to increase of Th17 and high cytotoxicity of CD8 T cells, which is further responsible for severe immune injury in this patient due to cytokine storm $[40,43,44]$. Other studies have also observed that during the early stage of the disease there is mild elevation of the liver enzymes which is not dangerous; however, sudden deterioration of the liver during the late stage of the disease is related to Systemic Inflammatory Response Syndrome (SIRS) and activated immune system due to viral infections. SIRS and immune damage can cause multiple organ damage including the liver $[39,44,45]$.

Drug toxicity: Another suggested mechanism which might be involved in liver damage during management of COVID-19 is the use of hepatotoxic drugs. Antipyretic (Acetaminophen), antivirals (oseltamivir, abidor, lopinavir, and ritonavir), antibiotics, steroids, certain herbal medications which are widely used for the treatment of COVID-19 have been reported with adverse reactions including liver damage [39,43,44].

\section{Conclusion}

Although COVID-19 primarily a respiratory disease and is responsible for pneumonia, gastrointestinal and manifestations are frequently associated with COVID-19. These manifestations are primarily associated with the presence of ACE2 receptors on the intestinal epithelial cells and cholangiocytes. The role of fecal viral shedding in the current pandemic and its role in the transmission of the disease needs to be evaluated further.

\section{References}

1. Wu Y, Ho W, Huang $Y$, Jin DY, Li S, et al. (2020) SARSCoV-2 is an appropriate name for the new coronavirus. Lancet 395: 949-950. Link: https://bit.ly/39VoB3b

2. World Health Organization. WHO announces COVID19 outbreak a pandemic. Link: https://bit.ly/2LQJX9K

3. Young BE, Ong SWX, Kalimuddin S, Low JG, Tan SE, et al. (2020) Epidemiologic features and clinical course of patients infected with SARS-CoV- 2 in Singapore. J Am Med Assoc 323: 1489-1494. Link: https://bit.ly/2M9KHqe

4. Wu F, Zhao S, Yu B, Chen YM, Wang W, et al. (2020) A new coronavirus associated with human respiratory disease in China. Nature 579: 265-269. Link: https://bit.ly/3iylBOz

5. Zhu N, Zhang D,WangW, Li X, Yang B, et al. (2020) China Novel Coronavirus Investigating and Research Team. A novel coronavirus from patients with pneumonia in China, 2019. N Engl J Med 382: 727-733.

6. Wang D, Hu B, Hu C, Zhu F, Liu X, et al. (2020) Clinical characteristics of 138 hospitalized patients with 2019 novel coronavirus-infected pneumonia in Wuhan, China. JAMA 323: 1061-1069. Link: https://bit.ly/39MwXtI

7. Mao R, Qiu Y, He JS, Tan JY, Li XL, et al. (2020) Manifestations and prognosis of gastrointestinal and liver involvement in patients with COVID-19: a systematic review and meta-analysis. Lancet Gastroenterol Hepatol 5: 667678. Link: https://bit.ly/3iAlL6u

8. Wu D, Wu T, Liu Q, Yang Z (2020) The SARS-CoV-2 outbreak:what we know. Int J Infect Dis 94: 44-48. Link: Link: https://bit.ly/3bZis8w

9. Zhang J, Wang S, Xue Y (2020) Fecal specimen diagnosis 2019 novel coronavirus-infected pneumonia. J Med Virol 92: 680-682. Link: https://bit.ly/3c6umxk

10. Leung WK, To KF, Chan PK, Chan HL, Wu AK, et al. (2003) Enteric involvement of severe acute respiratory syndrome-associated coronavirus infection. Gastroenterology 125: 1011-1017. Link: https://bit.ly/2NfSrrc

11. Xiao F, Tang M, Zheng X, Liu Y, Li X, et al. (2020) Evidence for gastrointestina infection of SARSCoV-2. Gastroenterology 158: 1831-1813. Link: https://bit.ly/3qyxE0q

12. Kim JY, Choe PG, Oh Y, Kim JY, Choe PG, et al. (2020) The first case of 2019 novel coronavirus pneumonia imported Into Korea From Wuhan, China: implication for infection prevention and control measures. J Korean Med Sci 35: e61. Link: Link: https://bit.ly/3p4QmMW

13. He X, Lau EH, Wu P, Deng X, Wang J, et al. (2020) Temporal dynamics in viral shedding and transmissibility of COVID-19. Nat Med 26: 672-675. Link: https://go.nature.com/3izeuF1

14. Guan WJ, Ni ZY, Hu Y, Liang WH, Ou CQ, et al. (2020) China Medical Treatment Expert Group for Covid-19. Clinical Characteristics of Coronavirus Disease 2019 in China. N Engl J Med 382: 1708-1720.

15. Borges do Nascimento IJ, Cacic N, Abdulazeem HM, von Groote TC, Jayarajah U, et al. (2020) Novel Coronavirus Infection (COVID-19) in Humans: A Scoping Review and Meta-Analysis. J Clin Med 9: e941. Link: https://bit.ly/2Y1atji 
16. Huang C, Wang Y, Li X, Ren L, Zhao J, et al. (2020) Clinical features of patients infected with 2019 novel coronavirus in Wuhan, China. Lancet 395: 497-506. Link: https://bit.ly/2XZE9gx

17. Shi H, Han X, Jiang N, Cao Y, Alwalid O, et al. (2020) Radiological findings from 81 patients with COVID-19 pneumonia in Wuhan, China: a descriptive study. Lancet Infect Dis 20: 425-434. Link: https://bit.ly/3sLeqGH

18. Zhang JJ, Dong X, Cao YY, Yuan YD, Yang YB, et al. (2020) Clinical characteristics of 140 patients infected with SARS-CoV-2 in Wuhan, China. Allergy 75: 1730-1741. Link: https://bit.ly/3sJ3FVA

19. Liu K, Fang YY, Deng Y, Liu W, Wang MF, et al. (2020) Clinical characteristics of novel coronavirus cases in tertiary hospitals in Hubei Province. Chin Med $J$ (Engl) 133: 1025-1031. Link: https://bit.ly/3o4AcSc

20. Cheung KS, Hung IF, Chan PP, Lung KC, Tso E, et al. (2020) Gastrointestina Manifestations of SARS-CoV-2 Infection and Virus Load in Fecal Samples from the Hong Kong Cohort and Systematic Review and Meta-analysis. Gastroenterology 159: 81-95. Link: https://bit.ly/3p4aTkT

21. Spinato G, Fabbris C, Polesel J, Cazzador D, Borsetto D, et al. (2020) Alterations in Smell or Taste in Mildly Symptomatic Outpatients With SARSCoV-2 Infection. 323: 2089-2090. Link: https://bit.ly/362GmMy

22. Giacomelli A, Pezzati L, Conti F, Bernacchia D, Siano M, et al. (2020) Selfreported olfactory and taste disorders in SARS-CoV-2 - a 330 patients: a cross-sectional study. Clin Infect Dis 71: 889-890. Link: https://bit.ly/362glaP

23. Hummel T, Landis BN, Huttenbrink KB (2011) Smell and taste disorders. GMS Curr Top Otorhinolaryngol Head Neck Surg 10: Doc04. Link: https://bit.ly/3sTUSjM

24. Norsa L, Valle C, Morotti D, Bonaffini PA, Indriolo A, et al. (2020) Intestinal ischemia in the COVID-19 era. Dig Liver Dis 52: 1090-1091. Link: https://bit.ly/3o5xX10

25. Tran J, Glavis-Bloom J, Bryan T, Harding KT, Chahine C, et al. (2020) COVID-19 patient presenting with initial gastrointestinal symptoms. Eurorad 26: 16654. Link: https://bit.ly/2LPcJHG

26. An P, Chen H, Jiang X, Su J, Xiao Y, et al. (2020) Clinical Features of 2019 Novel Coronavirus Pneumonia Presented Gastrointestinal Symptoms But Without Fever Onset. Link: https://bit.ly/394qQ4R

27. Carvalho A, Alqusairi R, Adams A, Paul M, Kothari N, et al. (2020) SARS-CoV-2 Gastrointestinal Infection Causing Hemorrhagic Colitis: Implications for Detection and Transmission of COVID-19 Disease. Am J Gastroenterol 115: 942-946. Link: https://bit.ly/39NJ2Pu

28. Gulen M, Satar S (2020) Uncommon presentation of COVID-19: Gastrointestina bleeding. Clinics and Research in Hepatology and Gastroenterology 44: e72-e76. Link: https://bit.ly/39TxuKf

29. Jin X, Lian JS, Hu JH, Gao J, Zheng L, et al. (2020) Epidemiological, clinical and virological characteristics of 74 cases of coronavirus-infected disease 2019 (COVID-19) with gastrointestinal symptoms. Gut 69: 1002-1009. Link: https://bit.ly/3p8kvuW

30. Martin TA, Wan DW, Hajifathalian K, Tewani S, Sha SL, et al (2020) Gastrointestinal Bleeding in Patients with Coronavirus Disease 2019:
A Matched Case-Control Study. Am J Gastroenterol 115: 1609-1616. Link: https://bit.ly/3qFb7iF

31. Chen N, Zhou M, Dong X, Qu J, Gong F, et al. (2020) Epidemiological and clinical characteristics of 99 cases of 2019 novel coronavirus pneumonia in Wuhan, China: a descriptive study. Lancet 395: 507-513. Link: https://bit.ly/3o8eoVP

32. Xu Z, Shi S, Wang Y, Zhang J, Huang L, et al. (2020) Pathological findings of COVID-19 associated with acute respiratory distress syndrome. Lancet Respir Med 8: 420-422. Link: https://bit.ly/35ZYTt0

33. Wander P, Epstein M, Bernstein D (2020) Bernstein D. COVID-19 Presenting as Acute Hepatitis. Am J Gastroenterol 115: 941-942. Link: https://bit.ly/392Rmvq

34. Huang Q, Herrmann A (2020) Fast assessment of human receptor-binding capability of 2019 novel coronavirus (2019-nCoV). Link: https://bit.ly/3qE5QI3

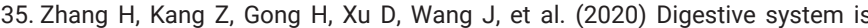
a potential route of COVID-19: an analysis of single-cell coexpression pattern of key proteins in viral entry process. Gut 69: 1010-1018. Link: https://bit.ly/39LMN7W

36. Deshmukh V, Motwani R, Kumar A, Kumari C, Raza K (2020) Histopathologica observations in COVID-19: a systematic review. Journal of Clinical Pathology 0: $1-8$

37. Xu H, Zhong L, Deng J, Peng J, Dan H, et al. (2020) High expression of ACE2 receptor of 2019-nCoV on the epithelial cells of oral mucosa. Int J Oral Sci 24 8. Link: Link: https://go.nature.com/2Y6ake9

38. Chai X, Hu L, Zhang Y, Han Y, Lu Z, et al. (2020) Specific ACE2 expression in cholangiocytes may cause liver damage after 2019-nCoV infection. Link: https://bit.ly/2NpGSOo

39. Hu LL, Wang WJ, Zhu QJ, Yang L (2020) Novel coronavirus pneumonia-related liver injury: etiological analysis and treatment strategy. Zhonghua Gan Zang Bing Za Zhi 28: 97-99. Link: https://bit.ly/3izck8n

40. Zhao JN, Fan Y, Wu SD (2020) Liver injury in COVID-19: A minireview. World J Clin Cases 8: 4303-4310. Link: https://bit.ly/3qJcwVx

41. Yang L, Wang W, Wang X, Zhao J, Xiao L, et al. (2019) Creg in Hepatocytes Ameliorates Liver Ischemia/Reperfusion Injury in a TAK1-Dependent Manner in Mice. Hepatology 69: 294-313. Link: https://bit.ly/3ivZSpK

42. Zhang XJ, Cheng X, Yan ZZ, Fang J, Wang X, Wang W et al. (2018) An ALOX12-12-HETE-GPR31 signaling axis is a key mediator of hepatic ischemiareperfusion injury. Nat Med 24: 73-83. Link: https://bit.ly/3o1IQBe

43. Yao N, Wang SN, Lian JQ, Sun YT, Zhang GF, Kang WZ et al. (2020) Clinica characteristics and influencing factors of patients with novel coronavirus pneumonia combined with liver injury in Shaanxi region. Zhonghua Gan Zang Bing Za Zhi 28: 234-239. Link: https://bit.ly/2XWf9qu

44. Cai Q, Huang D, Yu H, Zhu Z, Xia Z, et al. (2020) COVID-19: Abnormal liver function tests. J Hepatol 73: 566-574. Link: https://bit.ly/2LROf2q

45. Fan Z, Chen L, Li J, Cheng X, Yang J, et al. (2020) Clinical Features of COVID19-Related Liver Functional Abnormality. Clin Gastroenterol Hepatol 18: 1561 1566. Link: https://bit.ly/3bXbDo7

Copyright: @ 2021 Rama G, et al. This is an open-access article distributed under the terms of the Creative Commons Attribution License, which permits unrestricted use, distribution, and r eproduction in any medium, provided the original author and source are credited.

Citation: Rama G, Vandana K (2021) Gastrointestinal and hepatic involvement in patients with SARS-CoV-2 infection. Arch Clin Gastroenterol 7(1): 007-010. DOI: https://dx.doi.org/10.17352/2455-2283.000089 